\title{
Ore Dilution Estimation Model in Tanzania Southern Highland Zone: A Case of New Luika Gold Mine
}

\author{
Mtaita Charles Mtoni \\ Department of Civil Engineering, Mbeya University of Science and Technology, Mbeya, Tanzania
}

Email address:

mtaijunior@yahoo.com

To cite this article:

Mtaita Charles Mtoni. Ore Dilution Estimation Model in Tanzania Southern Highland Zone: A Case of New Luika Gold Mine. International Journal of Science and Qualitative Analysis. Vol. 4, No. 1, 2018, pp. 7-12. doi: 10.11648/j.ijsqa.20180401.12

Received: December 22, 2017; Accepted: January 16, 2018; Published: February 2, 2018

\begin{abstract}
This paper brings about understanding of the effect of ore dilution to the economics of mine and reveals that, mining ore dilution is one among factors affecting the economy of mining projects. Dilution factor varies within a single mine for different benches and zones due to changes seen in grade distribution and shape of ore body, also varies based on commodity price obtained. It was necessary to make sure that these variations were taken into account during designing or evaluating a mine. The study identified suitable methods that are supposed to be used for estimation of ore dilution level which are: Geological review method, loading and haulage methods. By checking the number of dilution from the data, the percentage of dilution, the total tons of ore and total tons of waste was computed by the formula of dilution, the computed average dilution estimation was found to be $64 \%$ which was then used in determination of an increase level of ore dilution by comparing obtained results to the standards ore dilution used by the company. Normally the company estimated $20 \%$ up to $23 \%$ as standard ore dilution which brings about the average of $21.5 \%$ standard ore dilution. Upon considering the factor of standard planned ore dilution in the Company, the finding proved that there is an increase by $42.5 \%$ ore dilution during operation each day. Upon considering factors concerned with the process of comminuting, the results shows that grade from grade control is $4.73 \mathrm{~g} / \mathrm{t}$ and grade of the final product is $3.95 \mathrm{~g} / \mathrm{t}$ and the grade difference is $0.78 \mathrm{~g} / \mathrm{t}$ where by factors like, leakage, slurry overflow, some other chemical agents in the CIL tanks that take place in the process like (CIL) Carbon In Leach process, crushing and grinding are taking into consideration. The study shows that, the dilution per hour in a given bench is above standard planned ore dilution. By checking the line graph from the findings it shows the dilution per hour in a given bench is higher than standard planned by the company which is $29 \%$.
\end{abstract}

Keywords: Ore Dilution, Southern Highland Zone, Ore Reserve, Geology, Waste, Cut-off Grade, Mine, Mill

\section{Introduction}

Ore dilution is well defined as waste materials that are not separated from the ore during the operation and are mined with ore [2]. Mathematically dilution can be expressed as the ratio of the mass of waste mined and sent to the mill to the total mass of ore and waste combined that are milled [1]. In estimation and calculation, normally ore dilution is represented in percentage [9]. Dilution tends to increase tonnage and reduce grade of ore during and after mining operation [4]. The New Luika Gold Mine (NLGM) which is operated by Shanta Mine Company Limited (SMCL's) and located within the Songwe district in Songwe Administrative Region is experiencing the problem of high level of ore dilution compared to the standard estimated ones. While the best procedures are done to identify and calculate all the other cost items of a project, no matter how small, it is common to make general assumptions about dilution instead of quantifying it. In case quantifying dilution, ore body should be well demarcated and the recovered volume should be efficiently measured [8]. Usually due to insufficient budget, time for studies and also lack of a well-defined methodology, the company tends to make general assumption instead of quantifying ore dilution. Rather than enumerating dilution in mining studies, it is common practice to assume a general dilution such as $5 \%$ and $10 \%$ for massive deposits and tabular shape deposits respectively [2]. Dilution raises the operation costs in the plant by expanding the tonnage of material to be processed [10]. Notwithstanding its direct effect on here and now pay of a mine, dilution causes critical 
changes in other factors that on the long term lower the general value of the project. For instance, it draws out the mine life by diminishing mill's effective limit. [3]. It also reduces the feed grade. In most cases, lower feed grade means lower mill recovery. Dilution also increases the cut-off grade which in turn reduces the overall ore utilization of a mine [6]. In some cases, to take advantage of economies of scale, mining operations tend to plan for higher mining rates [5]. Moving to a bigger size of operation implies less selectivity, thus more dilution. This is valid for all sort of deposit. Abnormal state and uncontrolled dilution may at last nullify the point of expanding production rates [7].

\section{Methodology}

\subsection{Methods}

Study of the geology in the initial stage for quantifying dilution was conducted. The use of geological block model that contains at least the following information: grade (s), specific gravity and rock types were considered.

The regional geology is characterized by deformed, folded, sheared and metamorphosed Paleoproterozoic rocks with major fold axes trending east southeast to west northwest.

The following main lithological units occur in the region:

\subsubsection{Ilunga Granite Formation}

The Ilunga Granite is situated in the northern portion of the Lupa Goldfield and is for the most part comprised of a medium to coarse grained leucogranite (aplogranite). Biotite and muscovite are ordinarily associated secondary minerals.

\subsubsection{Saza Granite Formation}

The Saza Granite is situated in the central part of the Lupa
Goldfield and comprises of various rock types including hornblende rich granites and hornblende-biotite rich granodiorites.

\subsubsection{Gneiss Formation}

The Gneiss Formation, the primary ore bearing host, is the lagest rock unit within the Lupa Goldfield. The Gneiss Formation has been subjected to no less than three granitic meddling occasions that have given rise to an assortment of rock types such as felsitic gneiss, biotite and hornblende granite gneiss, leucocratic granular gneiss. Diorite, granodiorite and granite rocks are evident within the Gneiss Formation.

Mineralized quartz veined targets are congregated within brittle-ductile to ductile deformational features of variable orientation.

Dilution was calculated using the information obtained fromloading and haulage mass of waste and ore and by the following formula;

$$
\text { oredilution }=\frac{\text { tonnsofwaste }}{\text { tonnsof } \text { wate }+ \text { tonnsofore }} \times 100 \%
$$

Data were collected at ILUNGA Pit (at block number F07G07G08HO8G09, E05E06) were mining operations took place. Information about tonnage of both waste and ore extracted from the blocks were taken and put into computations.

\subsection{Analysis}

\subsubsection{Geological Review}

Block tonnage, grade and content reconciliation

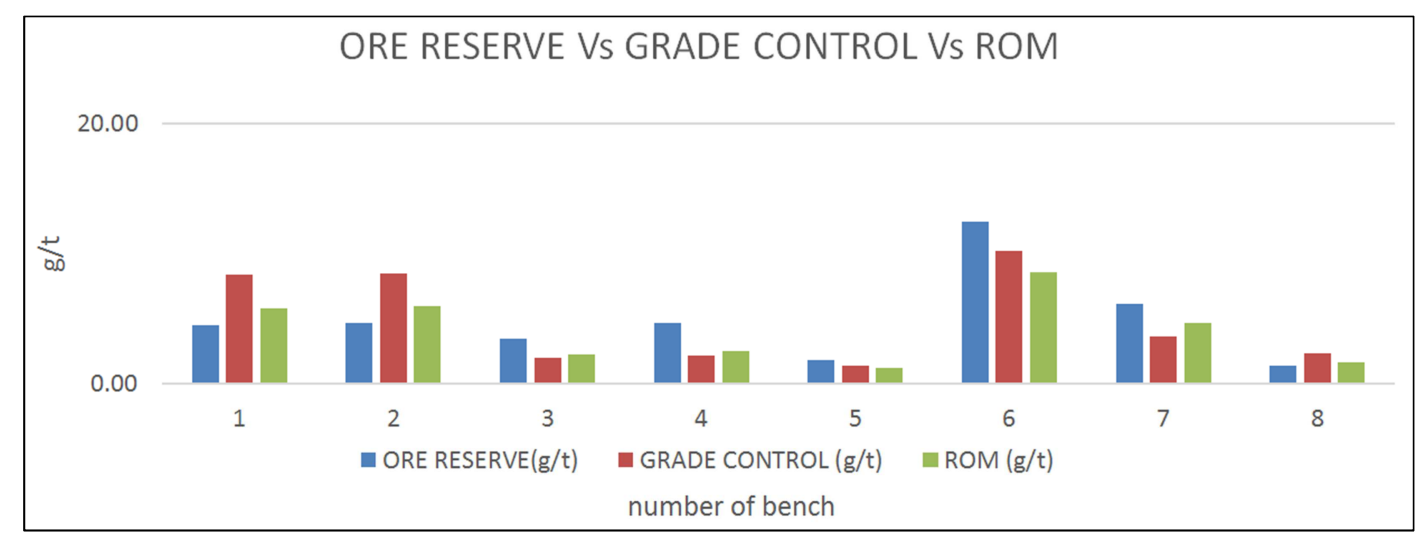

Figure 1. Shows distribution of ore reserve, grade control, ROM in gram per tons.

Table 1. Shows block tonnage, grade and content reconciliation.

\begin{tabular}{|c|c|c|c|c|c|c|c|c|c|c|c|}
\hline \multicolumn{12}{|c|}{ Block Tonnage, Grade and Content Reconciliation - 2016} \\
\hline \multirow{2}{*}{ Pit } & \multirow{2}{*}{ Block } & \multirow{2}{*}{ Target level } & \multicolumn{3}{|c|}{ Ore Reserve } & \multicolumn{3}{|c|}{ Grade Control } & \multicolumn{3}{|c|}{ Delivered to ROM } \\
\hline & & & Tonnes & $g / \mathbf{t}$ & $\mathbf{0 Z}$ & Tonnes & $\mathrm{g} / \mathrm{t}$ & $\mathbf{0 Z}$ & Tonnes & $\mathrm{g} / \mathbf{t}$ & $\mathbf{O z}$ \\
\hline \multirow{6}{*}{ LK } & G05G06 & 965 & 3,608 & 4.46 & 517 & 2,656 & 8.35 & 713 & 1,374 & 5.73 & 253 \\
\hline & G05G06 & 960 & 3,597 & 4.67 & 540 & 2,949 & 8.43 & 799 & 4,791 & 5.94 & 915 \\
\hline & E09E10E11 & 955 & 3,942 & 3.50 & 444 & 4,050 & 2.00 & 260 & 7,470 & 2.26 & 543 \\
\hline & F07E08E09 & 950 & 7,178 & 4.63 & 1,068 & 9,550 & 2.21 & 679 & 12,462 & 2.54 & 1,018 \\
\hline & E12 & 980 & 1,224 & 1.79 & 70 & 1,830 & 1.44 & 85 & 1,474 & 1.27 & 60 \\
\hline & Total & & 19,549 & 4.20 & 2,640 & 21,035 & 3.75 & 2,536 & 27,571 & 3.15 & 2,789 \\
\hline
\end{tabular}




\begin{tabular}{|c|c|c|c|c|c|c|c|c|c|c|c|}
\hline \multirow{2}{*}{ Pit } & \multirow{2}{*}{ Block } & \multirow{2}{*}{ Target level } & \multicolumn{3}{|c|}{ Ore Reserve } & \multicolumn{3}{|c|}{ Grade Control } & \multicolumn{3}{|c|}{ Delivered to ROM } \\
\hline & & & Tonnes & $g / \mathbf{t}$ & $\mathbf{o z}$ & Tonnes & $g / \mathbf{t}$ & $\mathbf{o z}$ & Tonnes & $g / t$ & $\mathrm{Oz}$ \\
\hline \multirow{3}{*}{$\mathrm{BC}$} & F07G07G08H08G09 & 905 & 7,063 & 12.42 & 2,820 & 7,911 & 10.22 & 2,599 & 6,868 & 8.56 & 1,890 \\
\hline & E05E06 & 915 & 4,023 & 6.12 & 792 & 3,819 & 3.64 & 447 & 4,255 & 4.67 & 639 \\
\hline & Total & & 11,086 & 10.13 & 3,612 & 11,730 & 8.08 & 3,046 & 11,123 & 7.07 & 2,529 \\
\hline \multirow{3}{*}{ JM } & H10H11 & 1025 & 7,334 & 1.43 & 337 & 5,500 & 2.35 & 416 & 7,320 & 1.64 & 386 \\
\hline & Total & & 7,334 & 1.43 & 337 & 5,500 & 2.35 & 416 & 7,320 & 1.64 & 386 \\
\hline & & & & & & 38,265 & 4.73 & 5,998 & 46,014 & 3.95 & 5,704 \\
\hline
\end{tabular}

The following graph shows grade of material sent to ore reserve, grade control and ROM

Data was collected from grade control process which was done at the following benches as follow at Luika pit (G05G06, E09E10E11, E12), BC Pit (F07GO7G08H08G09, E05E06), JM Pit (h10h11).

\subsubsection{Loading and Haulage Mass of Waste and Ore}

ILUNGA Pit (at block number F07G07G08HO8G09, E05E06)

Table 2. Shows number of trips per truck and total material loaded.

\begin{tabular}{|c|c|c|c|c|c|c|c|c|c|c|c|c|}
\hline \multicolumn{13}{|c|}{ WEEKLY TALLY SHEET } \\
\hline NO & Equipment ID & 7:00 & 8:00 & 9:00 & $10: 00$ & $11: 00$ & $12: 00$ & $14: 00$ & $15: 00$ & $16: 00$ & $17: 00$ & Total \\
\hline \multicolumn{13}{|c|}{ WASTE } \\
\hline 1 & ADT 16 & IIII & IIIII & IIII & II & IIIII & I & III & IIIII & III & I & 33 \\
\hline 2 & ADT 18 & III & IIII & I & IIIII & III & II & III & II & III & IIII & 31 \\
\hline 3 & ADT 06 & IIII & I & III & III & III & IIII & III & I & III & IIII & 29 \\
\hline 4 & ADT 14 & IIIII & IIII & IIII & II & II & II & II & II & II & IIII & 29 \\
\hline 5 & ADT 22 & II & III & II & III & IIII & IIII & IIII & II & IIII & I & 30 \\
\hline 6 & ADT 21 & IIII & II & II & IIII & II & II & III & I & II & III & 25 \\
\hline 7 & ADT 15 & III & IIIII & I & IIII & I & II & IIII & IIII & II & II & 28 \\
\hline 8 & ADT 17 & II & IIII & IIII & III & IIII & III & IIII & IIII & II & II & 32 \\
\hline 9 & ADT 01 & IIIIII & III & I & IIII & IIII & II & I & II & III & IIII & 30 \\
\hline 10 & ADT 02 & IIII & III & II & IIII & I & II & IIII & IIII & IIII & IIII & 32 \\
\hline 11 & ADT 03 & III & III & II & IIII & II & IIII & IIII & IIII & II & II & 30 \\
\hline \multirow[t]{3}{*}{12} & ADT 19 & III & IIII & III & IIII & I & III & II & III & I & III & 27 \\
\hline & TOTAL LOADS & 43 & 41 & 30 & 42 & 32 & 31 & 37 & 34 & 31 & 35 & 353 \\
\hline & ORE & & & & & & & & & & & \\
\hline 1 & ADT 14 & III & I & I & IIII & I & I & I & IIII & I & III & 20 \\
\hline 2 & ADT 18 & I & I & II & I & I & IIII & IIII & III & IIII & I & 22 \\
\hline 3 & ADT 22 & II & II & I & II & IIII & II & IIII & II & I & I & 21 \\
\hline 4 & ADT 21 & II & IIII & III & II & IIII & I & I & I & IIII & II & 24 \\
\hline 5 & ADT 15 & III & I & I & I & I & I & IIII & IIII & I & I & 18 \\
\hline 6 & ADT 03 & II & II & IIII & I & III & II & III & II & IIII & I & 24 \\
\hline 7 & ADT 19 & II & IIII & II & II & IIII & I & II & IIII & III & I & 25 \\
\hline 8 & ADT 17 & IIII & II & IIII & I & I & III & I & I & IIII & I & 22 \\
\hline \multirow[t]{2}{*}{9} & ADT 06 & III & II & II & I & II & I & IIII & I & IIII & II & 22 \\
\hline & TOTAL LOADS & 22 & 19 & 20 & 15 & 21 & 16 & 24 & 22 & 26 & 13 & 198 \\
\hline
\end{tabular}

Where (I) symbol represents the number of trips carried by the ADT (articulated dump truck) whereby each tucks carries approximately39.5 tons of both waste and ore direct to stock pile (ore) and to the TSF (tailing storage facility) waste.

To find the total amount of materials carried by ADT in each time, 39.5 tons is multiplied by the number of trips in that particular time.

ILUNGA Pit (at block number F07G07G08HO8G09, E05E06)

Table 3. Show a mass in tons of waste and ore and their total masses.

\begin{tabular}{|c|c|c|c|c|c|c|c|c|c|c|c|c|}
\hline \multicolumn{13}{|c|}{ WEEKLY TALLY SHEET } \\
\hline NO & Equipment ID & $7: 00$ & $8: 00$ & $9: 00$ & 10:00 & 11:00 & 12:00 & 14:00 & 15:00 & 16:00 & 17:00 & Total \\
\hline \multicolumn{13}{|c|}{ WASTE } \\
\hline 1 & ADT 16 & 158 & 197.5 & 158 & 79 & 197.5 & 39 & 118.5 & 197.5 & 118.5 & 39.5 & 1303 \\
\hline 2 & ADT 18 & 118.5 & 158 & 79 & 197.5 & 118.5 & 79 & 118.5 & 79 & 118.5 & 158 & 1224.5 \\
\hline 3 & ADT 06 & 158 & 39.5 & 118.5 & 118.5 & 118.5 & 158 & 118.5 & 39.5 & 118.5 & 158 & 2527.5 \\
\hline 4 & ADT 14 & 197.5 & 158 & 158 & 79 & 79 & 79 & 79 & 39.5 & 79 & 158 & 1106 \\
\hline 5 & ADT 22 & 79 & 118 & 79 & 118.5 & 158 & 158 & 158 & 79 & 158 & 79 & 1184.5 \\
\hline
\end{tabular}




\begin{tabular}{|c|c|c|c|c|c|c|c|c|c|c|c|c|}
\hline \multicolumn{13}{|c|}{ WEEKLY TALLY SHEET } \\
\hline NO & Equipment ID & $7: 00$ & 8:00 & 9:00 & 10:00 & 11:00 & 12:00 & 14:00 & 15:00 & 16:00 & 17:00 & Total \\
\hline 6 & ADT 21 & 158 & 79 & 79 & 158 & 79 & 79 & 118.5 & 79 & 79 & 118.5 & 2290.5 \\
\hline 7 & ADT 15 & 118.5 & 197.5 & 39.5 & 158 & 39.5 & 79 & 118.5 & 39.5 & 79 & 79 & 948 \\
\hline 8 & ADT 17 & 79 & 158 & 158 & 118.5 & 158 & 118.5 & 158 & 158 & 79 & 79 & 1264 \\
\hline 9 & ADT 01 & 273 & 118.5 & 39.5 & 158 & 158 & 79 & 39.5 & 79 & 118.5 & 158 & 1221 \\
\hline 10 & ADT 02 & 158 & 118.5 & 79 & 158 & 39.5 & 79 & 158 & 158 & 158 & 158 & 1264 \\
\hline 11 & ADT 03 & 118.5 & 118.5 & 79 & 158 & 79 & 158 & 158 & 158 & 79 & 79 & 1185 \\
\hline \multirow[t]{2}{*}{12} & ADT 19 & 118.5 & 158 & 118.5 & 158 & 39.5 & 188.5 & 79 & 118.5 & 39.5 & 118.5 & 1136.5 \\
\hline & $\begin{array}{l}\text { TOTAL LOADS } \\
\text { ORE }\end{array}$ & 1734.5 & 1619 & 1185 & 1659 & 1264 & 1294 & 1422 & 1224.5 & 1224.5 & 1382.5 & 14009 \\
\hline 1 & ADT 14 & 118.5 & 39.5 & 39.5 & 158 & 39.5 & 39.5 & 39.5 & 158 & 39.5 & 118.5 & 790 \\
\hline 2 & ADT 18 & 39.5 & 39.5 & 79 & 39.5 & 39.5 & 158 & 158 & 118.5 & 158 & 39.5 & 869 \\
\hline 3 & ADT 22 & 79 & 79 & 39.5 & 79 & 158 & 79 & 158 & 79 & 39.5 & 39.5 & 1659 \\
\hline 4 & ADT 21 & 79 & 158 & 118.5 & 79 & 158 & 39.5 & 39.5 & 39.5 & 158 & 79 & 948 \\
\hline 5 & ADT 15 & 118.5 & 39.5 & 39.5 & 39.5 & 39.5 & 39.5 & 158 & 158 & 39.5 & 39.5 & 711 \\
\hline 6 & ADT 03 & 79 & 79 & 158 & 39.5 & 118.5 & 79 & 118.5 & 79 & 158 & 39.5 & 948 \\
\hline 7 & ADT 19 & 79 & 158 & 79 & 79 & 158 & 39.5 & 79 & 158 & 118.5 & 39.5 & 987.5 \\
\hline 8 & ADT 17 & 158 & 79 & 158 & 39.5 & 39.5 & 118.5 & 39.5 & 39.5 & 158 & 39.5 & 869 \\
\hline \multirow[t]{2}{*}{9} & ADT 06 & 118.5 & 79 & 79 & 39.5 & 79 & 39.5 & 158 & 39.5 & 118.5 & 79 & 829.5 \\
\hline & TOTAL LOADS & 869 & 750.5 & 790 & 592.5 & 829.5 & 632 & 948 & 869 & 987.5 & 513.5 & 7781.5 \\
\hline
\end{tabular}

From the table 3 above, total amount of waste in tons is obtained by taking summation of all masses of waste from each time throughout the day. The same way, total amount of ore in tons is obtained.

\section{Results and Discussion}

\subsection{Geological Review}

From the geological point of view, the grade from grade control is $4.73 \mathrm{~g} / \mathrm{t}$ and grade of the final product is $3.95 \mathrm{~g} / \mathrm{t}$, therefore the difference is $0.78 \mathrm{~g} / \mathrm{t}$ where by factors are like, leakage, slurry overflow, some other chemical agents in the CIL tanks that take place in the process like (CIL) Carbon In
Leach process, crushing and grinding.

\subsection{Loading and Haulage Mass of Waste and Ore}

The following is the formula used to compute values of ore dilution;

$$
\text { Dilution }=\frac{\text { wastetons }}{\text { oretons }+ \text { wastetons }} \times 100 \%
$$

The following table shows the waste tonnage, ore tonnage and dilution per hours and general dilution that calculated by the above formula:

Table 4. Shows dilution per hour, waste tonnage and ore tonnage.

\begin{tabular}{|c|c|c|c|c|c|c|c|c|c|c|}
\hline Time & $7: 00$ & 8:00 & 9:00 & 10:00 & 11:00 & $12: 00$ & $14: 00$ & $15: 00$ & $16: 00$ & $17: 00$ \\
\hline waste tonnage & 1734.5 & 1619 & 1185 & 1659 & 1264 & 1294 & 1422 & 1224.5 & 1224.5 & 1382.5 \\
\hline ore tonnage & 869 & 750.5 & 790 & 592.5 & 829.5 & 632 & 948 & 869 & 987.5 & 513.5 \\
\hline Dilution \% & 66.6 & 68.3 & 60 & 73.7 & 60.4 & 67.2 & 60 & 58.5 & 55.4 & 72.9 \\
\hline
\end{tabular}

The following graph shows the dilution versus time

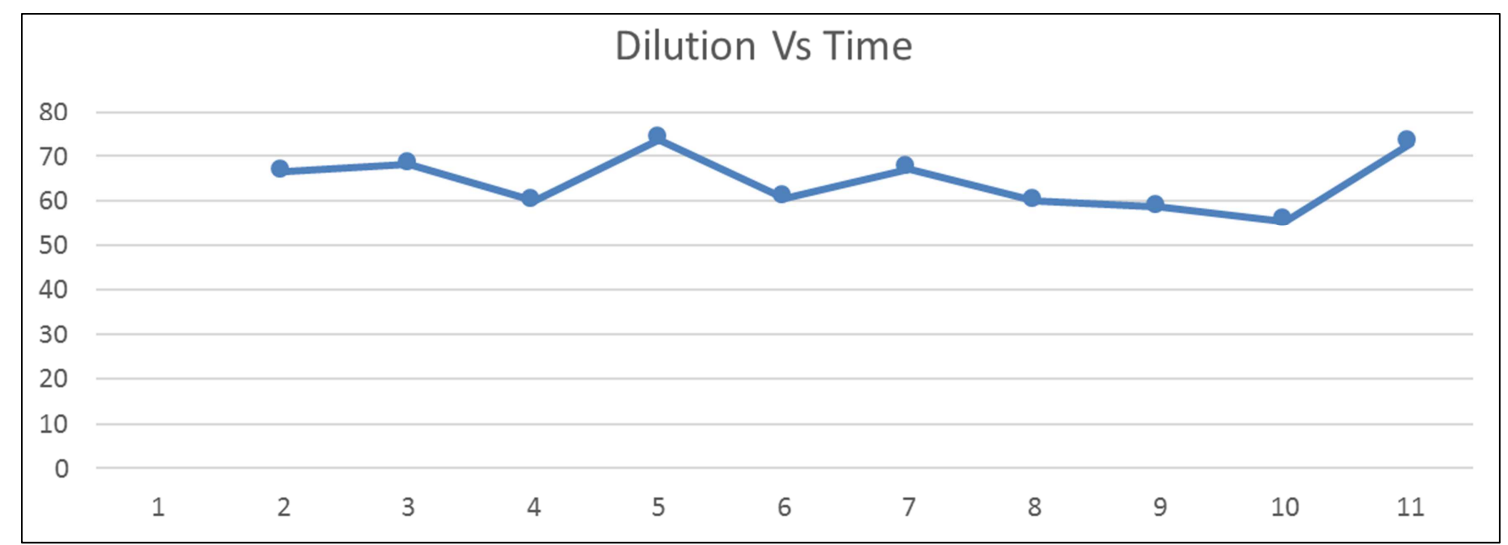

Figure 2. Graph shows variation of dilution against time. 


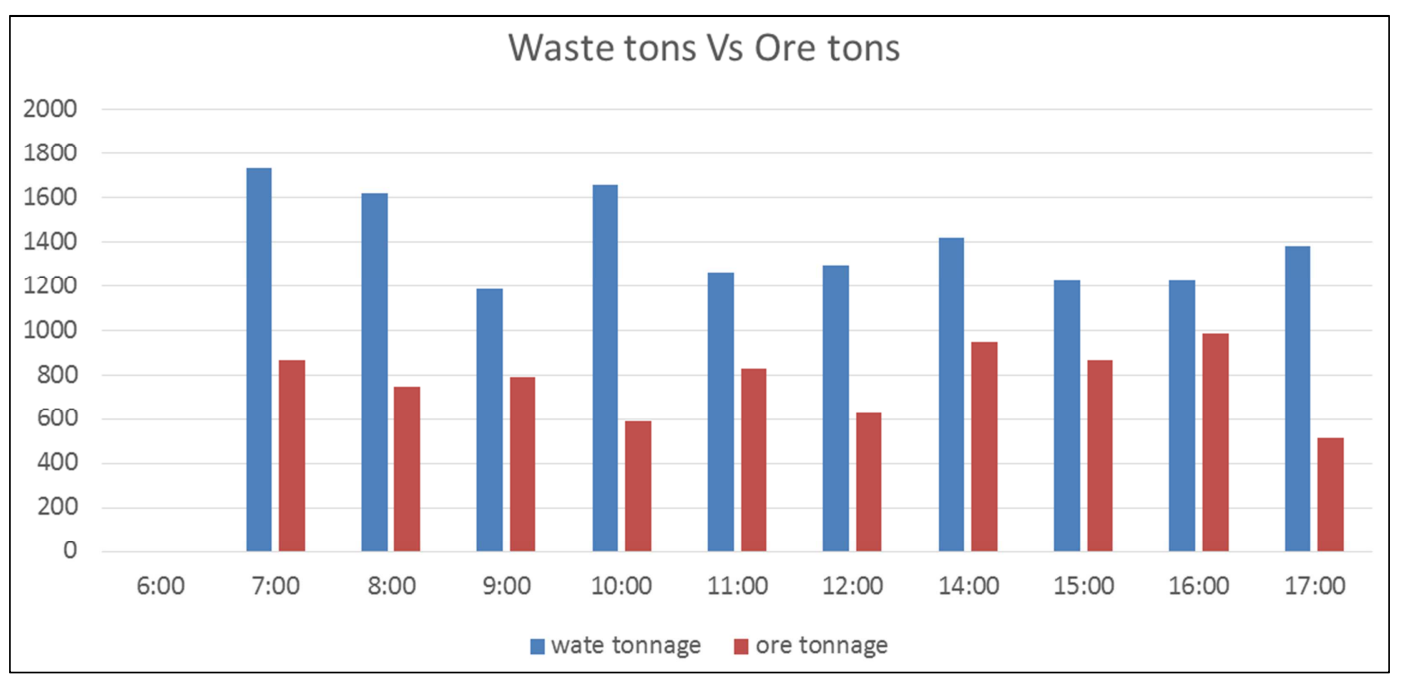

Figure 3. Shows waste tons against ore tons.

The combination graph of ore tons, waste tons and dilution is as follows.

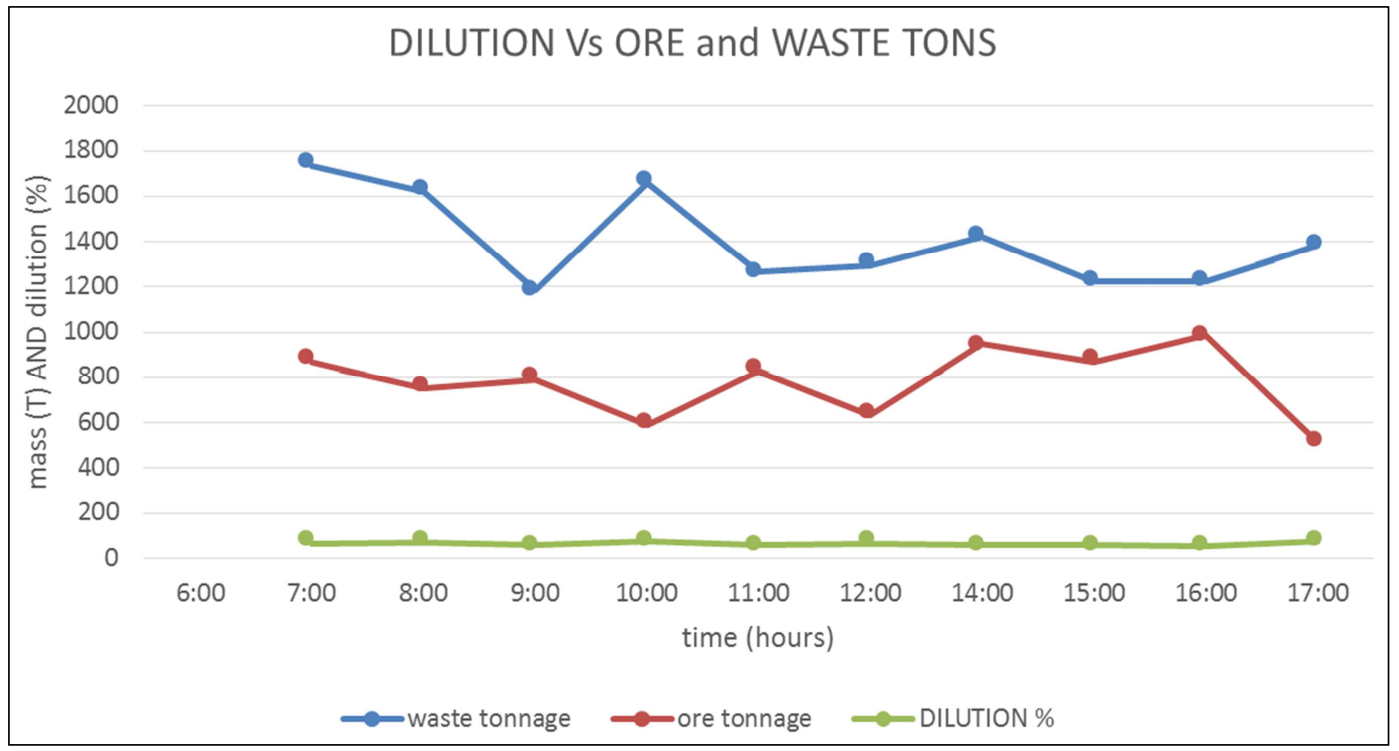

Figure 4. Shows dilution (\%), mass of waste and mass of ore in tons.

From figure 4 above it is seen how percentage of dilution varies as time changes, from morning at 7:00am up to evening at 5:00pm. But deviation per hour is not too high throughout the day, though when the average is compared to the standard planned ore dilution deviation seems to be very high.

From figures above the study shows that, in each hour there is more waste than ore which leads to high percentage of ore dilution. The wastes contaminated with ore are inevitable in any mining operation; therefore different methods are to be used in order to minimize the effect of ore dilution and maximize productivity.

\section{Conclusion}

Average Ore Dilution of $64.3 \%$ discovered which is much greater compared to the standards planned ore dilution used by the company. Since the standard acceptable ore dilution by the company is $21.5 \%$, therefore there is an increase of $42.8 \%$ more than standard planned ore dilution. This shows high risk of poor production that the company may run through during operation and production.

Findings reveal that, dilution can occur due to various reasons as discussed in this paper, although it cannot be controlled but it can be quantified by using Equivalent Linear Over break Sloughing (ELOS).

From geological model it was observed that grade at ROM is very low compared to grade at Ore reserve and grade control. This implies that ore dilution is higher compared to the standard ore dilution.

According to this finding, in case of no data during operation, it is recommended to use any technique in order to estimate dilution. Quantifying dilution before operation is necessary in order to achieve optimum economic evaluation 
of the project and also to improve mine design. In case of high dilution detected it is a starting moment to reduce it by altering the mine plans. For instance by reducing bench height it will help to mine more selectively and improve production while increasing unit production cost because of small operation scale.

\section{References}

[1] Parker H. M. (2012). Reconciliation principles for the mining industry. Published by Maney on behalf of the Institute of Materials, Minerals and Metallurgy and the AusIMM, maneypublishing.com.

[2] Anoush Ebrahimi, P. Dilution factor for open pit mining projects.

[3] Gerald D. Crawford (2004) Pincock Allen and Holt, Pincock perspectives, Dilution and ore Recovery, issue NO. 60.
[4] A. Sinclair, G. Blackwell. (2002), Applied Mineral Inventory Estimation, Cambridge University Press.

[5] Wright, A., 1983. Dilution and Mining Recovery, Erzmetal, Vol 36.

[6] Elbrond, J., 1994. Economic Effect of Ore Losses and Rock Dilution; CIM Bulletin, Vol 87, No 978, pp. 131-134.

[7] Ingler, D., 1984. Mining Methods, Rock Dilution and Ore Losses.

[8] Anderson B, Grebenc B (1995) Controlling dilution at the Golden Giant mine. In: Proceedings of the 12th CIM mine operators' conference, Timmins, February 1995.

[9] F. Leite et al, J. F Domingo, I. Carasco, V. Gouveia, I. Navarro, F. Lozano. (2014). Dilution, ore grade and blast movement calculation model.

[10] Wang, W., Huang, S., Wu, X., \& Ma, Q. (2011). Calculation and Management for Mining Loss and Dilution under $3 D$ Visualization Technical Condition. 